J. Perinat. Med. 16 (1988)

\section{Morphohistometric investigations in placentas of gestational diabetes}

\author{
Frank Stoz ${ }^{1}$, Roland A. Schuhmann', Barbara Haas ${ }^{1}$ \\ ${ }^{1}$ Department of Obstetrics and Gynecology, University of Ulm, West Germany \\ ${ }^{2}$ Department of Obstetrics and Gynecology, Worms, West Germany
}

\section{Introduction}

An increase in perinatal morbidity and mortality demonstrates that maternal gestational diabetes in neither a minor nor harmless variant of diabetes mellitus $[1,8,15]$. Since the high fetal risk factor in the overt from a diabetes mellitus is partly due to morphologically manifest placental insufficiency $[2,3,4,5,6,7,13,14]$, we were interested to determine if histopathologic changes also occur in gestational diabetes. To this end, we examined morphometrically the placental terminal villi of 26 patients with gestational diabetes. Results from our previous studies of normal [9] and diabetic placentas [14] served as controls.

\section{Material and methods}

Twenty-six patients with pathologic blood glucose levels after a positive oral $100 \mathrm{~g}$ glucose tolerance test of J. B. O'SulLivan [10] form the basis of this study. During pregnancy, 14 patients could be managed on diet alone whereas 12 required insulin therapy. The placentas studied were all from gestations greater than the 37 th weeks. Gestational age in all cases was established by early sonographic evaluation. The clinical data of the overt diabetes group demonstrated no marked deviations when compared with the control group. With gestational diabetes, there was a marginally higher incidence of obesity and multiparity.

Placentas were fixed in $10 \%$ formalin immediately after delivery, and random sections were taken and stained with hematoxylin and eosin. Fifty terminal villi in the periphery of the placentas or cotyledons were morphometrically studied. Three separate sections were examined for each patient.
The following parameters were determined:

- villous surface area and circumference,

- total surface area, circumference,

- number of villous vessels,

- degree of vascularization,

- number and length of epithelial plates,

- villous circumference coverage by epithelial plates,

- number of vessels directly involved in resorption via epithelial plates.

Statistical calculations were performed on the TR 440 (Siemens) at the computer center of the University of Ulm by analysis of variance.

The study presented is based on the same measurements, methods, and instruments (Kontron, Videoplan) as were the controls. The image analysis system used has a failure rate of $<1 \%$, with an operator's failure rate of $1.5 \%$.

\section{Results}

The values for the surface areas of terminal villi $\left(2210 \pm 160 \mu \mathrm{m}^{2}\right)$ were found to lie almost midway between those for normal placentas (1977 $\left.\pm 190 \mu^{2}\right)$ and those for the diabetic control group $\left(2484 \pm 296 \mu \mathrm{m}^{2}\right)$. There is no statistically significant difference (Figure 1). This also holds true for the villous circumference (Table I). The total surface areas of the villous vessels are more reduced in gestational diabetes $\left(620 \pm 210 \mu^{2}\right)$ compared to overt diabetes mellitus $(631 \pm 217$ $\mu \mathrm{m}^{2}$ ) with a significance of $\mathrm{p}<0.01$ when compared to normal placentas with $706 \pm 230 \mu \mathrm{m}^{2}$ (Figure 2) as well as the total circumference of 


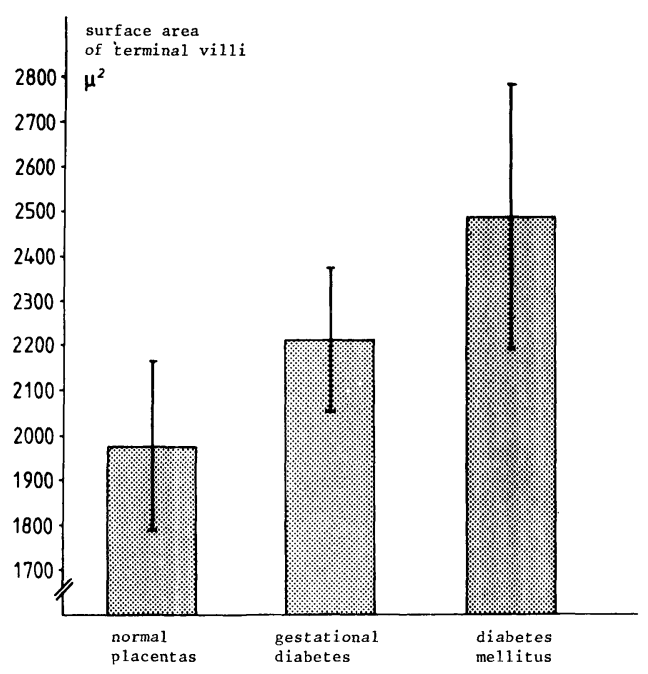

Figure 1. Surface area of placental terminal villi in gestational diabetes versus normal and diabetes mellitus placentas.

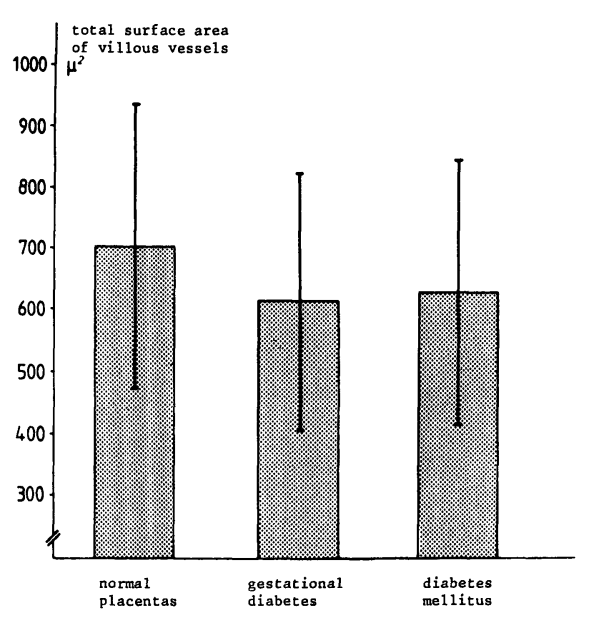

Figure 2. Total surface area of placental villous vessels in gestational diabetes versus normal and diabetes mellitus placentas.

Table I. Parameters of villi and vessels in gestational diabetes as compared to those in normal as well as diabetes mellitus placentas.

\begin{tabular}{llll}
\hline & $\begin{array}{l}\text { normal placentas } \\
(\mathrm{N})\end{array}$ & $\begin{array}{l}\text { gestational } \\
\text { diabetes }(\mathrm{G})\end{array}$ & $\begin{array}{l}\text { overt diabetes } \\
\text { mellitus (D) }\end{array}$ \\
\hline villous circumference & $157 \pm 8 \mu$ & $163 \pm 9 \mu$ & $\begin{array}{l}183 \pm 11.5 \mu \\
\mathrm{D} / \mathrm{N} \mathrm{p}<0.01\end{array}$ \\
total circumference of villous vessels & $180 \pm 36 \mu$ & $\mathrm{NS}$ & $165 \pm 37 \mu$ \\
& & $\mathrm{G} / \mathrm{N} \mathrm{p}<0.05$ & $\begin{array}{l}168 \pm 35.5 \mu \\
\mathrm{D} / \mathrm{N} \mathrm{p}<0.05\end{array}$ \\
number of vessels & $4 \pm 0.5$ & $3.5 \pm 0.4$ & $3.5 \pm 0.4$ \\
& & $\mathrm{G} / \mathrm{N} \mathrm{p}<0.01$ & $\mathrm{D} / \mathrm{N} \mathrm{p}<0.01$ \\
\hline
\end{tabular}

Table II. Parameters of epithelial plates of terminal villi in gestational diabetes as compared to normal as well as diabetes mellitus placentas.

\begin{tabular}{|c|c|c|c|}
\hline & $\begin{array}{l}\text { normal placentas } \\
(\mathrm{N})\end{array}$ & $\begin{array}{l}\text { gestational } \\
\text { diabetes }(\mathrm{G})\end{array}$ & $\begin{array}{l}\text { over diabetes } \\
\text { mellitus (D) }\end{array}$ \\
\hline length of epithelial plates & $29 \pm 5.4 \mu$ & $\begin{array}{l}32 \pm 5.3 \mu \\
\mathrm{NS}\end{array}$ & $\begin{array}{l}36 \pm 8.1 \mu \\
\mathrm{D} / \mathrm{N} \mathrm{p}<0.05\end{array}$ \\
\hline number of epithelial plates & $2.5 \pm 0.4$ & $\begin{array}{l}2.3 \pm 0.6 \\
\mathrm{NS}\end{array}$ & $\begin{array}{c}1.9 \pm 0.3 \\
\mathrm{D} / \mathrm{N} \mathrm{p}<0.001\end{array}$ \\
\hline $\begin{array}{l}\text { villous circumference coverage } \\
\text { by epithelial plates }\end{array}$ & $18.5 \pm 5 \%$ & $\begin{array}{l}21.1 \pm 5 \% \\
\mathrm{NS}\end{array}$ & $\begin{array}{l}19.6 \pm 6 \% \\
\text { NS }\end{array}$ \\
\hline number of vessels with epithelial plates & $68 \pm 7 \%$ & $\begin{array}{l}66.1 \pm 8 \% \\
\text { NS }\end{array}$ & $\begin{array}{l}67 \\
\mathrm{NS}\end{array}$ \\
\hline
\end{tabular}




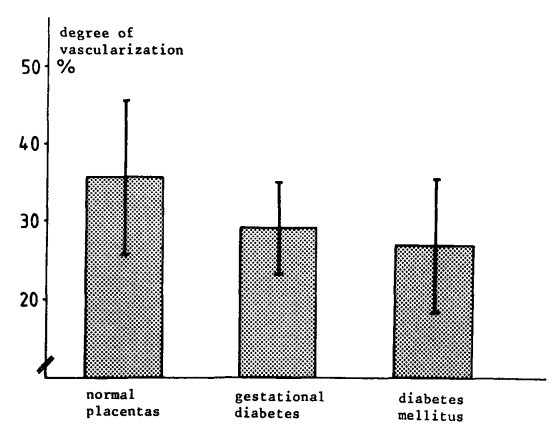

Figure 3. Degree of vascularization of placental terminal villi in gestational diabetes versus normal and diabetes mellitus placentas.

villous vessels (Table I). The number of vessels is reduced compared to the normal group ( $p<0.01$ ), but corresponds to the values of the diabetic group (Table I). For the degree of vascularization (gestational diabetes: $29.1 \pm 12 \%$, overt diabetes $26.9 \pm 8.5 \%$, normal: 35.8 $\pm 10 \%$ ), the number of vessels involved in resorption via epithelial plates as well as the parameters of the epithelial plates were mostly found to lie between the values of normal and diabetic placentas, with only moderate differences between the groups (Table II, Figure 3).

\section{Discussion}

There is general agreement regarding the retarded maturation of surface areas of terminal villi from diabetic patients $[3,5,6]$. The question whether these pathologic changes are correlated either with the White stages $[11,14,16,17]$ or with blood glucose levels $[2,4]$ is a controversial issue. Gestational diabetes is characterized by short duration combined with apparently normal blood glucose levels before pregnancy. It usually responds well to therapeutic blood glucose control during pregnancy.

In overt diabetes, retarded maturation is most conspicuous in the placental vasculature $[4,13$, 14]. Surprisingly, we observed even lower values in gestational diabetes when compared with diabetic pregnancies which is in accordance with SENFT [12].

The retarded maturation of terminal villi affects the same structures in gestational diabetes as in overt diabetes although less pronounced. Placental insufficiency may occur in gestational diabetes as a result of the retarded vascular maturation.

\begin{abstract}
Perinatal morbidity and mortality are increased in both overt and gestational diabetes. Since retardation of placental development has been documented in overt diabetes, we, thus, examined morphometrically the terminal villi of 26 patients with gestational diabetes in order to determine if there is an immaturity of placental development. Investigation of villous surface, degree of vascu-
\end{abstract}

Keywords: Gestational diabetes, morphometry, placenta.

\section{Zusammenfassung}

Morphohistometrische Untersuchungen an Plazenten bei Gestationsdiabetes

Die kindliche Morbidität und Mortalität ist nicht nur bei manifestem Diabetes mellitus, sondern auch bei Gestationsdiabetes erhöht. Bezüglich des manifesten Diabetes muß diese Tatsache zum Teil mit den bekannten Reifungsstörungen der Plazenta erklärt werden.

In einer morphometrischen Studie untersuchten wir deshalb die Terminalzotten der Plazenten von 26 Patientinnen mit Gestationsdiabetes mit der Fragestellung, ob eine Reifungsstörung in den für den materno-fetalen Stoffaustausch essentiellen Terminalzotten vorliege. larization, and development of epithelial plates yielded values lying somewhere between those of non-diabetic patients and those of patients with overt diabetes. Only the surface areas of the vessels were reduced to levels lower than in overt diabetes. Our findings appear to explain the occasional development of acute placental insufficiency.
Die Diagnose Gestationsdiabetes wurde bei allen $\mathrm{Pa}$ tientinnen durch erhöhte Blutzuckerwerte nach einem pathologischen oralen $100 \mathrm{~g}$ Glucose-Toleranz-Test gesichert. Während es möglich war, 14 der Frauen durch die ganze Schwangerschaft nur mit Diät alleine zu behandeln, mußten 12 Patientinnen auf Insulin eingestellt werden. Alle untersuchten Plazenten stammten aus der 37. bis 41. Schwangerschaftswoche. Für die Morphometrie benutzen wir das halbautomatische elektronische Bildanalyseverfahren Videoplan, Kontron.

Die Werte für die Zottenquerschnittsflächen und die Zottenumfänge lagen genau zwischen denen bei mani- 
festem Diabetes mellitus und denen der normalen Kontrollgruppe ohne signifikante Unterschiede zu beiden. Dasselbe trifft für den Vaskularisationsgrad und die Entwicklung der Epithelplatten zu.

Die Gesamtquerschnittsfläche der Zottengefäße jedoch war sogar noch gegenüber der bei manifestem Diabetes stark reduzierten Gefäßfläche mit einem Signifikanzniveau von $\mathrm{p} 0,01 \mathrm{im}$ Vergleich $\mathrm{zu}$ den Normalwerten verringert. Unsere Ergebnisse könnten deshalb die gelegentlich bei Gestationsdiabetes auftretende akute Plazentainsuffizienz erklären.

Schlüsselwörter: Gestastionsdiabetes, Histometrie, Morphometrie, Plazenta.

\section{Résumé}

Explorations morphohistométriques des placentas de diabètes gestationnels

La mortalité et la morbidité fatale périnatale ne sont pas seulement augmentées lors des diabètes patents mais également lors des diabètes gestationnels. On connaît bien le retard significatif du développement placentaire lors de diabètes patents. Toutefois, nous avons examiné de façon morphométrique les villosités terminales chez 26 patientes avec un diabète gestationnel afin de déterminer s'il existe une immaturité du développement placentaire. On a examiné des coupes effectuées au hasard au niveau de la périphérie des cotylédons, ces coupes sont sonsidérées comme représentatives des zones d'échanges foto-maternelles. Toutes les patientes avaient un test de tolérance au glucose pathologique $(100 \mathrm{~g}$ de

Mots-clés: diabète gestationnel, morphométrie, placenta. glucose per os). Pendant la grossesse, le régime seul a été suffisant chez 14 patientes alors que chez 12 autres, une insulinothérapie a été nécessaire. Les placentas étudiés étaient tous d'un âge gestationnel supérieur ou égal à 37 semaines. Les études morphométriques ont été réalisées à l'aide d'un système d'analyse d'images électroniques semi-automatique (Kontron-Vidéoplan). Les surfaces villositaires, le degré de vascularisation et le développement des couches épithéliales ont été interprétés comme intermédiaires entre ceux des patientes normales et ceux des patientes avec un diabète patent. Seules les surfaces des vaisseaux étaient plus réduites que celles trouvées lors des diabètes patents. Nos résultats semblent expliquer la survenue occasionelle d'une insuffisance placentaire aigüe.

\section{References}

[1] Beischer NA, CN De GaRis: Unexplained intrauterine death near term. Aust NZ J Obstet Gynaecol 26 (1986) 99

[2] BJOERK O, B PERSSON: Villous structure in different parts of the cotyledon in placentas of insulin-dependent diabetic women. A morphometric study. Acta Obstet Gynecol Scand 63 (1984) 37

[3] Boyd PA, A ScotT, JW Keeling: Quantitative structural studies on placentas from pregnancies complicated by diabetes mellitus. Br J Obstet Gynaecol 93 (1986) 31

[4] GePPERT M, FD Peters, J GePPert: Zur Histomorphometrie der Zottenvaskularisation von Placenten diabetischer Mütter. Geburtsh u Frauenheilk 42 (1982) 628

[5] HAUST MD: Maternal diabetes mellitus - effects on the Fetus and placenta. Chapter 8 (1981) 201

[6] Hills D, GA Irwin, S Tuck, R BaIm: Distribution of placental grade in high-risk gravidas. Am J Radiol 143 (1984) 1011

[7] LAURETI E: Osservazioni istologiche sui villi coriali di placente diabetiche. (Histological observations on the chorionic villi of the diabetic placenta). Boll Soc Ital Biol Sper 58 (1982) 695

[8] Lowy C, RW Beard, J GoldschmidT: The UK diabetic pregnancy survey. Acta endocrinol 277 (1986) 86
[9] Noack EJ, F Stoz, RA Schuhmann: Morphometrische Untersuchungen an Planzentazotten. Z Geburtsh u Perinat 185 (1981) 155

[10] O'Sullivan JB, CM Mahan: Criteria for the oral glucose tolerlance test in pregnancy. Diabetes 13 (1978) 278

[11] Semmler K, P Emmrich, K Furhmann, E Goedel: Reifungsstörungen der Plazenta in Relation zur Qualität der metabolischen Kontrolle während der Schwangerschaft beim insulinpflichtigen und Gestationsdiabetes. Zentralbl Gynäkol 104 (1982) 1494

[12] Senft HH, HJ Foedisch, O BellmanN: Placentafunktionsstörungen bei Gestationsdiabetes - eine morphometrische Analyse. Abstractband 46. Tagung der Dtsch Ges für Gynäkologie u Geburtshilfe Düsseldorf, Sept 1986

[13] SHADMI AL, C BaHARI: Histochemical study of diabetic placentae. In: SCHENKER JG, ET RIPPMANN, D WEINSTEIN (eds): Recent advances in pathophysiological conditions in pregnancy. Proceedings of the Fifteenth Congress of the Society for the Study of Pathophysiology of Pregnancy - Organization Gestosis Jerusalem, Israel, 11-16 September 1983. Excerpta Medica Amsterdam-Oxford-Princeton, 1984 
[14] Stoz F, RA SchuHmann, A Schmid: Morphometric investigations in terminal villi of placentas in diabetics in relation to the White classification. $J$ Perinat Med 15 (1987) 193

[15] Stoz F, I Zeller, W Beischer: Gestationsdiabetes - Konsequenzen aus der Dokumentation der bisher in der Universitäts-Frauenklinik Ulm betreuten Patientinnen. Probl Perinat med 15 (1987) 122

[16] Teasdale F: Histomorphometry of the Human Placenta in Class B Diabetes Mellitus. Placenta 4 (1983) 1
[17] Teasdale F: Histomorphometry of the Human Placneta in Class C Diabetes Mellitus. Placenta 6 (1985) 69

Received November 4, 1987. Revised January 22, 1988. Accepted February 19, 1988.

Dr. med. Frank Stoz

Universitäts-Frauenklinik Ulm

Prittwitzstraße 43

D-7900 Ulm, West Germany 